\title{
Meat in traditional Serbian cuisine
}

\author{
Milan Z. Baltic ${ }^{1}$, Janjic Jelena ${ }^{1}$, Milka Popovic ${ }^{2}$, Tatjana Baltic ${ }^{3}$, Marija Boskovic ${ }^{1}$, Marija Starcevic ${ }^{4}$, \\ Danijela Sarcevic ${ }^{3 *}$
}

A b s t r a c t: The use of meat in traditional Serbian cuisine can be divided into three periods. The first period is the time from the arrival of Slavs in the Balkans, through the Middle Ages to the early $19^{\text {th }}$ century. The second period, the $19^{\text {th }}$ and the first half of the $20^{\text {th }}$ centuries, can be marked as special due to significant changes that impacted traditional Serbian cuisine, compared to the first period. It was a period during which the Europeanization of Serbia took place in all spheres of life, including cuisine. After World War II, Serbia and many surrounding countries eperienced a great surge in industrialization in all economic fields, including that of food production. The last sixty years has seen the globalization of our food supply, with food being transported globally from one part of the world to another, and which resulted in neglected traditional, local cuisines. Therefore, many countries, including Serbia, recognize a need for preserving traditional cuisine. This recognition has initiated several mechanisms for maintaining Europe's gastronomic heritage. Preservation of traditional cuisine in Serbia has special significance for tourism development.

Keywords: tradition, nutrition, history, heritage.

\section{Introduction}

At a geographic, historic crossroads between East and West, Serbia has always been, and still is, interesting economically, politically and militarily to other, larger states. Hence, there were frequent conflicts (in the twentieth century alone there were five), shifting borders and population migrations. All of this has had a significant impact on the overall life of the people of Serbia, as well as on their cuisine, food preparation, food habits and their whole culinary culture. Serbian cuisine, without exaggeration, can be described as a gastronomic cauldron, a mixture of different cuisines, being the legacy of the original homeland with influences from Greece and Rome plus Byzantium, the East and the West. That makes Serbia host to a heterogeneously contrasting variety of foods.

Serbian cuisine can be regarded as very tasty and moderately spicy, able to satisfying to all the senses. Meat, especially barbecued meat and different types of roast meat, has an important place, and most ordinary meals contain at least one meat serving (Sarcevic et al., 2011) Traditional Serbian dishes are very generous, while ingredients are not expensive and preparation is not complex. Generally, Serbian people like to prepare food and enjoy consuming the resultant meals. The term "national cuisine" can be used only conditionally, because there is no truly homogenous national cuisine.

Culinary culture is an important and inseparable part of the cultural heritage of each nation. Foods that are consumed, customs and habits related to food preparation and behavior at the table are part of the spiritual riches and heritage of each nation that is transmitted from generation to generation.

\section{Traditional Serbian cuisine in the Middle Ages}

There are almost no data about the cuisine of Serbian people in the centuries after their arrival in the Balkans. These Slavic peoples certainly brought with them their cuisine traditions. For these massive, strong people, adept in boat making and skilled fishermen, the Balkans was an arid environment. Their Slavic homeland was rich with pastures and water. However, the Balkan Peninsula did have pastures and forests, which provided the means for animal

${ }^{1}$ University in Belgrade, Faculty of Veterinary Medicine, Bulevar oslobodjenja 18, 11000 Belgrade, Republic of Serbia;

'University in Novi Sad, Faculty of Medical Science, Institute for public health Vojvodina, Futoski put 121,21000 Novi Sad, Republic of Serbia;

3Institute of Meat Hygiene and Technology, Kacanskog 13, 11000 Belgrade, Republic of Serbia;

${ }^{4}$ Army of Serbia.

*Corresponding author: Danijela Sarcevic, danijela.sarcevic@inmes.rs 
husbandry, and hence, the use of milk and meat in local diets. It is believed that the early Slavs also brought the today almost forgotten and certainly lost, breed of pig, the siska pig (Baltic et al, 2013, Hrasnic et al., 1964). Serbia still has traditional pig breeding and it is quite understandable that pork continues to be the most common type of meat. In medieval Serbia, pigs and sheep were the most common and cherished meat animal species. Meat was sold fresh, and professional butchers are mentioned in various Serbian cities of the time. Butchers had to comply with different regulations, particularly those regulating prices. Besides fresh meat, people traded in salted meat. Meat was usually dried and used in winter. Meat products (smoked meat, sausages) were also familiar, especially in coastal areas. Medieval communities utilized significant amounts of wild game meat (wild pigs, chamois, deer, roe deer, hares, wild ducks, geese, partridges, pigeons). Besides meat, the most important product of animal origin was cheese, and by medieval times, several kinds of cheese were produced. Fish (freshwater and marine) also played an important role in the local cuisine. Fresh fish was sold in retail markets in cities situated on the shores of the sea or rivers, but salted fish was also accessible to consumers inland. Besides fish, other seafood (octopus, crabs, clams) was available on the tables of the rulers, feudal lords and nobles, and during fasting periods in local monasteries (Marjanovic-Dusanic and Popovic, 2004).

Among foods of plant origin, bread prepared from cereals (wheat, barley, millet, oats or sorghum) took pride of place. Vegetables (cabbage, garlic, onion, radishes, turnips, pumpkins, melons, lentils, broad beans, peas, poppy seeds, rice) and fruits (walnuts, hazelnuts, pears, apples, cherries, cherry, rowan) were used in the local cuisine. Foods of plant or animal origin were prepared with the addition of fat, tallow or oil, particularly olive oil. Lard was extensively used in the daily cuisine because ordinary, poorer people mainly bred pigs (Spremic, 2004).

At that time in Serbia, people had two meals daily, so breakfast was introduced later from the West. By the mid-nineteenth century, people ate mainly stews, and the spoon was the main, and often only, cutlery item. However, while European peoples had, for six or seven centuries, eaten relatively fatty foods and with their fingers, from the time of the Nemanjic dynasty, Serbs at court and the nobility ate with golden forks. In fact, the German emperor Frederick Barbarossa, on his crusade, was hosted by Serbian Prince Stefan Nemanja in Nis during 1189 , and experienced eating with a fork for the first time (Baltic et al, 2010c).
For the average Serbian host, the collapse of the Serbian state and the arrival of the Ottoman Empire was not much influence on the cuisine. They ate twice a day (lunch before midday, between 10.00 and 11.00 and an evening meal before dusk). For those who worked in the fields, an additional snack meal was prepared.

\section{Traditional Serbian cuisine in the $19^{\text {th }}$ up to the mid-20 ${ }^{\text {th }}$ century}

In the $19^{\text {th }}$ century, Europeanization engulfed all areas of public and private life in Serbia. It was quite understandable for the country to desire its place in Europe, after centuries spent under Ottoman occupation. The influx of foreigners (diplomats, merchants, governors) influenced life in Serbia, the changes at first visible among upper social classes, but which soon spread to the middle class. The most interesting changes occurred in the private lives of wealthy, urban families, and the greatest changes were around the position of women and their household duties. The housewife was now tasked with supervising domestic chores and taking care of guests and how they were served. Cooking was left to the maidservant and food purchases to the house boy. The changes were also reflected in food preparation and serving. In the best hotel in Belgrade at the time, Novo Zdanje, breakfast was served at eight o'clock, lunch at noon (daily four different meals, and on Thursdays and Sundays, six meals), while dining was a la carte (Grujic, 1992).

We cannot say with certainty which meals were on the menu of the mid-19 $9^{\text {th }}$ century, but it is known that the food was simple but plentiful. Soup, boiled beef (Rindfleisch) and stewed vegetables were consumed daily, but on Thursdays and Sundays, roast meat and on Sundays, cakes, were prepared. Cheese and fruit were always available. Remainders of stews and cheese were served for dinner, and during winter, this meal was supplemented with mutton or fried sausages (Zujovic, 1986). Great feasts were infrequent, but on Sundays, friends were invited to lunch. Guests would come every day for brunch (pork crackling, offal sausages - kavurma - and cheese) (Zujovic, 1986). Breakfast was served between seven and eight o'clock, lunch between midday and one o'clock, and dinner at seven in the evening. The eating times of urban families were maintained until the Second World War, and choice of meals changed as the country grew and contacts with other European nations expanded. In one cookbook from 1877, many recipes for dishes from different backgrounds and requiring various 
ingredients were recorded (Popovic Midzina, 1877). The hostess had to take into account the balance between different dishes, ensuring there were not more soups than solid foods, or more sweets than savoury foods. Mixed dishes were intentionally created to produce enticing menus. In the menu prepared by Stojan Novakovic (1913), lunch options were: pureed bean soup with fried bread, veal stew with dumplings and butter-taiga for desert; hamburger steak, roast potatoes, dumplings with cheese and fruit, or; green soup, beef with horseradish sauce, lentils with bacon, veal chops and vegetables. For dinner, according to the same source (Novakovic, 1913), choices were: fried chicken, potatoes boiled in salted water and fruit; veal chops, spinach and fruit, and; chicken with white sauce, donuts and fruits. Naturally, official lunches and dinners offered different fare from the daily diet. At the official dinners at the Obrenovic's court, meals were served in a certain order. Thus, for dinner on 13 December 1894, the following items were served: poultry soup; Rhine salmon in a crayfish sauce; garden stake; garnished lobster; quail with rice; goose liver pate à la Parisienne; pineapple; pheasant on a spit; peas with roasted bread pieces; chocolate candy; ice cream and fruit. In the United Kingdom in 1913 during the reign of King George V, the following were served for one dinner: Indian-style soup; crab; lamb fillet; poultry meat in aspic; quail with vegetables; cold meat jelly; asparagus with sauce; and various types of cakes, strawberries and wild berries. Comparing these official Serbian and English royal family dinners, it is clear the Serbian court did not lag behind the table of the King of England. Everyday court lunches and dinners were more simple: soup; fish as an appetizer; roast meat as the first main course poultry as a second main course; cheese and fruit for dessert (Colak-Antic, 2004).

After the First World War, urban society was so modernized that wealthy households sometimes ordered in food, despite the fact that they had their own servants. Complicated, savory specialties for a cold buffet were usually ordered in, such as goose liver in aspic or hot roll of puff pastry stuffed with a filling of brain, mushrooms and chicken meat. One respectable Belgrade family had 26 dinner guests who were served soup, spinach pie, meat pie, ham with horseradish, cauliflower salad with mayonnaise, celery with goose liver pate sandwiches, pastry with ham, sweets and fruit.

Food is just one segment of culture, but it is an excellent indicator of the real state of society. From the 1850s until the Second World War, middle class society in Serbia lived and ate according to European standards. The diet changed, especially in urban environments in which different cultures intersected. A new meal was accepted (breakfast was introduced into the daily menu), attitudes towards food changed and eating times during the day were modified. These changes occurred not only in Belgrade, but spread to other Serbian cities (ColakAntic, 2004).

People in rural areas lived and ate differently to the urban population. Rural meal patterns depended on the seasons and cycles of agricultural production. From late spring to early autumn, food was balanced and diverse, because there was plenty of fresh vegetables and fruits. Despite the hard field work at this time of year, food consumption was moderate and meals were light but frequent (four meals a day). In winter, the diet was more uniform, and people ate a greater proportion of fatty foods in larger portions. From this it could be concluded that people were moderately behaved when the nature was generous, until at the time of shortages, people ate plenty of food. In rural areas, some customs were retained steadfastly, to become rituals. So, the holiday roast pig or lamb was always prepared by male members of the household. For feasts (the family patron saint feast, weddings, funerals), many different dishes were prepared, most of which included meat (or fish if the celebration was at a time of fasting), but all the dishes were just a prelude to the main course. This was a spit-roasted pig or lamb, which stood in the middle of the table, taking a central and important place in the table presentation (Prosic-Dvornic, 2004).

The beginnings of active culinary literacy in Serbia in the late $19^{\text {th }}$ and early $20^{\text {th }}$ century was related largely to the female population, best shown through a real explosion of cookbooks which started to be published. These cookbooks, beside recipes, contained advice and instructions for housewives. Spasenija Pata Markovic wrote one of the most famous cookbooks which was published in 1907 and has had 24 editions to date. In the Introduction, among other things, she wrote: "Food is what keeps us alive. And that is why is not irrelevant what a person eats, how much he eats and how the meal is prepared. The diversity of food and different ways of preparing food are of great importance for the human body. Only diversified food can provide all the ingredients we need: proteins, fat, starch, sugar, various salts, vitamins, etc., and the lack of these ingredients contributes to a variety of disorders in the body" (Markovic, 1907). This way of thinking about food is completely in line with the modern approach to nutrition. From 1907 until today, cookbooks, with various types of content, and with different scopes and purposes, became numerous and found 
their way into the hands of many satisfied customers. Serbs from the mid- $19^{\text {th }}$ century onwards generally had three meals a day (the newly-introduced breakfast, plus lunch and dinner) and the most abundant was, and is, lunch. Until the mid-19 ${ }^{\text {th }}$ century, the only two meals were lunch and dinner, as is practiced in monasteries today. It is interesting that Nikola Tesla wrote: "It is natural that a person eats twice a day" (Janic, 2010).

\section{Traditional Serbian cuisine in the second half of the $20^{\text {th }}$ century}

The peoples living in Serbia during the second half of the $20^{\text {th }}$ century have had exposure to a very a rich and interesting culinary culture, which is the result of the country's geographic location, and contacts and influence from other cultures, especially Oriental and Central European ones, but is also due to the hedonistic habits and material development of the populace in the country. In the $20^{\text {th }}$ century, much has changed in the world and in Serbia, especially after the Second World War. Much of what for centuries has been our heritage, has, within a brief moment in history, become worthless, obsolete. Restaurants have contributed to the standardization of cuisine in Serbia, and eventually to making gastronomy's ordinary shop window that of fast food. Over a considerable period of time, sit-down, more traditional restaurants (as opposed to those that are largely fast food outlets) have been replaced by ethnic and fusion restaurants that often do not pay much attention to traditional cuisine (Baltic et al., 2010c).

Today, the real symbol of Serbian national cuisine, above all, is grilled meat. Our meals can appear greasy and heavy to many foreigners, which is a result of the fact that in Serbia, pork is the most common type of meat consumed (it accounts for 70 to $80 \%$ of consumed meat). Pork and/or lard have been the subject of many debates, and very frequently have been accused of causing cardiovascular diseases in humans. However, recently, the opinion that lard has been groundlessly and unscientifically demonized as causing cardiovascular diseases has started to be heard (Baltic et al. 2010b; Boskovic et al., 2015). Regardless, though, of warnings of the catastrophic consequences that consuming fatty foods has on the human body at any age, fatty but delicious dishes always have strong appeal to human desires and appetites. Fat is not only nutritious and a basic requirement in human nutrition, but is also a food supplement that enriches and intensifies the flavor of other ingredients. Man is has always attributed great and manifold significance to fat. Lard, regardless of the part of the world and culinary traditions, has long enriched meals premised heavily on grains or other forms of carbohydrate. Fat, whether vegetable, dairy or animal fat, and no matter what culinary tradition, improves meals prepared from vegetables and other plant ingredients. It is known that breaded and fried foods carry large amounts of fat, but these fats also contribute to the diversity and fullness of meal taste (Baltic et al., 2010c).

In the latter part of the $20^{\text {th }}$ century and to date, globalization has induced large and significant, sometimes serious or even irreparable damage in the food culture of nations, including our own. Globalization has led to a loss of traditional cuisine, since large, multinational companies have interests that we all have the same diet and that everyone purchases food from the same manufacturers. Environmental changes, the race for economic profit and need to produce more food have contributed to the disappearance of traditional varieties of fruit, vegetables and animal breeds, plus a number of fish species. The basic human right to life and food should include the right to enjoy food. This implies that societies and communities have some responsibility for preserving their own food cultures and traditional methods of food preparation in order that food enjoyment is feasible in the future, all in accordance with the principles of sustainable development (Pulen, 2004a).

Industrial production in all areas, including that of food, has wrought a series of changes. In industrial food production, the distribution system is the weak link between food and those who consume it. The culinary sector has now moved outside the household, and the food distribution system allows a wide variety of plant and animal products to be at our disposal, thus significantly changing the system of decision-making about our cuisines. Industrialization encroaches on the social function of the kitchen and partially excludes the act of eating from those of food preparation and indeed, from the kitchen. Industrialization has, in fact, two sides: production and transformation. In the production of foods of animal origin, animal nutrition has become a thing apart from human consumption of the food, so that foods like meat, eggs and dairy products have become devoid of animal attributes. In small manufacturing households that keep animals for their own use, and where the animals live in "a state of nature", animals are treated and cared for similarly to people. The animal is man's companion, enjoys a very special status and becomes the subject of enormous attention (Pulen, 2004b). This is 
confirmed by customs from our region, including that of women getting up at the moment oxen (working cattle) passed by them. Also, dairy cows or working livestock were practically never slaughtered for consumption in their own household (Baltic et al., 2010a). Transformation in the food industry implies the efforts of industry to offer consumers something that has an identity, which is not anonymous, which is not without spirit, and which is acceptable socially. This is confirmed by the data showing modern food producers want to ameliorate the connotations of industrial food production by using advertising to draw consumers closer. This is usually achieved by pictures that are linked to traditional cuisine or food production, or product names such as "grandma's cake".

Industrialized food is produced in vast quantities, and it may be, overall, less recognizable and famous than traditional food, but more worrisome. Food, however, is not an ordinary consumer product; it enters the body, taking part in the maintenance of its integrity, but also in the construction of personal identity. Food binds man to nature, cuisine and behavior at the table in each society, and harbors a unique relationship between nature and culture. Industrialized food disturbs that arrangement and can cause issues that provoke fear, so that consumers now question where their food comes from, what changes it has suffered and who has handled it?

Food preservation, transport speed and temperature control have enabled food to be transferred from one to the other end of the world. Food in all its forms, from the seeds of plants to live animals to ready-to-eat meals, is now shipped from country to country by major road, sea, rail and air services. At the same time, it is not rare that traditional meals are found in exotic places, to which they were never previously linked. However, relocation and moving food - globalization of the food industry - have also contributed to the fact that man today, as never before, has a variety of affordable food (Pulen, 2004a).

This millennium is an era when we have increasingly less time for long feasts and when everyone lives faster. This acceleration of life dictates insipidity. People in the modern world have come to the fact that they cannot afford to lose a single moment of time. In an effort to save that precious time, by consuming fast food, we have chewed over our futures and our own souls. "I keep time," said the Romanian poet Jon Karajon. As a result, we have come to the point that we have lost part of our souls and may now be trying to turn back, if this is at all possible (Domazet, 2004).

Fast food is not a novelty in modern diets. In fact, fast food has existed since the time when people began to gather in public places to trade, socialize or participate in any joint activities. Markets, fairs, streets and squares and all other places of public assembly, are all traditional social places where special diets were developed, intended primarily for passengers or strangers passing through. When talking about modern fast food, speed and convenience are the most important characteristics, all in order to meet the requirements arising out of a specific type of demand. At the same time, it is important to preserve many elements of the traditional meal. When fast food is consumed, there is no cutlery, no dish washing, no tables, no chairs surrounding it. Fast food has long been accepted throughout the world, so the main aim of modern producers is not to completely satisfy our hunger, but to make their products enjoyable, practical and regularly consumed (Janjic et al., 2015). Previously, prior to globalization, fast food was in accordance and harmony with the culture and environment in which it was created and in which it put down roots. However, only after the Second World War was it accepted all over the planet, so it is now a kind of global culinary tradition and habit that knows no cultural barriers, and, thereby, must meet a huge number of different culinary traditions and flavors (Rozen, 2004) .

This type of nutrition probably originally appeared among travelers and farmers. The main desirability of fast food is the fact that the humans simply love to hold food in their hands, because that enables the experience of unparalleled closeness and intimacy with the food that is consumed. This is one of the reasons why, and to what extent, the humble but popular sandwich can be almost a complete meal, since a mixture of ingredients can go together between two slices of bread. The variety and mix of different tastes, aromas and textures from the food from which a sandwich is prepared are an enjoyable mixture. Sandwiches can be open, that is, prepared so that various foods and spices, alone or in appealing combinations, are applied to one slice of bread. Among many people, including those in Serbia, this slice of bread was, until recently, but now more rarely, usually smeared with lard, lightly salted and spiced with sweet pepper.

The expansion of fast food and all phenomena related to it appears to have occurred because of what fast food offers to consumers - direct and efficient food access. This primarily refers to the satisfaction felt by consumers because of their complete sensory stimulus due to the presence of favorite ingredients, the fullness of taste, texture and aroma. Fast food feels good to most of the people who consume it; it offers meals and tastes to consumers 
which people have always sought after and craved, and which they have not always managed to afford.

In contrast, globalization and industrialization of food has also led to the fact that the products are standardized and uniform. This is often the reason for the loss of specific sensory characteristics. Despite strong pressure from international companies to place their products, national and regional efforts to preserve the cuisine specifics of any one country and one people have not vanished. Thus, in Serbia, cabbage with pork and rustic bread appears on city restaurant tables and take-out outlets, as do baked potatoes, various kinds of meat grilled over charcoal, local meat products and products from local fields, opposing industrial products from multinationals. In some countries, the movements described as new cuisine from local soil, which have many activities including, for example, publication of ethnic cuisine recipes, have become guardians of traditional gastronomy. This, however, often isn't just a book of old, traditional recipes, but can also include local habits and dining customs throughout the history of the region or country, anecdotal records of evening gatherings and older carnivals, and old photographs of related scenes. International companies such as McDonald's are largely aware of this type of movement and adapt the fast food they offer to local habits. Thus, while in the US, chips are served with ketchup, in France, the accompaniment is mayonnaise (Rozen, 2004; Janjic et al., 2015).

However, we cannot say that fast food has no opponents. The Slow Food movement is registered to date in about 150 countries, including in Serbia. Proponents of this movement have revolted against the quick and unhealthy eating of food and fast life of the modern world, the disappearance of people's interests in the food they eat and the disappearance of local culinary traditions. The Slow Food movement encourages slow and prolonged enjoyment of food from harvest to consumption, but also awareness of our permanent responsibility towards food and its origins (Baltic et al., 2010).

\section{The gastronomic map of Serbia today}

The gastronomic map of Serbia is based on geographically and historically defined areas, as well as similarity of gastronomic culture, and so is divided into four regions (Vojvodina, Central and Western Serbia, Eastern Serbia and Southwest Serbia). The cuisine of Vojvodina is significantly different to the cuisine of other parts of Serbia. This is understandable considering the influence from Austrian, German, Hungarian and Slovakian cuisines. This cuisine is characterized by significant use of pasta. Some municipalities within the region have a specific population composition. This is because settlers from different parts of former Yugoslavia after the Second World War brought with them their own habits in eating and preparing meals, and which have now been maintained for over 60 years. This means that their third generation descendants are now preparing those dishes in traditional ways (Zagorac et. al, 2010). Meat is often cooked in sauces, like a stew, or eaten as roast. A characteristic stew is prepared with mutton, chicken, fish, beef, venison or rooster. Another traditional dish is smoked fish, such as perch or bream. Famous meat products include sausages like kulen and other types of fermented sausages, Petrovska klobasa, sausages for roasting, dry ham and bacon. In Vojvodina there is long tradition of production of fermented sausages of various diameters, ham and bacon. Fermented sausage are produced maily from pork meat (Sremski kulen, Lemesko sausage, Sremska sausage, Petrovska klobasa) (Baltic et al., 2011). These sausage types have protected geographical indication (PGI). Almost forgotten meat dishes include wild-style quail, minced meat with cabbage (galupci) and fried pork brains. Vrsac ham, produced in the middle of Banat in Vojvodina, also has PGI status. Lemesko sausage, Petrovska klobasa and Vrsac ham are produced exclusively in artisanal conditions, typically smallholder households. Sremska sausages, Sremski kulen and Sremska salami are produced in industrial and also in artisanal conditions. Traditional meat products such as fermented sausages, ham and bacon are produced in the period from November until April because of favorable climatic conditions (colder seasons) (Vukovic et al., 2011a; Vukovic et al., 2011b; Ikonic et al., 2010; Ivanovic et al., 2016; Stevanovic et al., 2016).

Central and Western Serbia, regions between the Morava and Drina Rivers and to the south to Kraljevo, are regions of traditional livestock production. Here, people consume significant amounts of meat and milk products. Among them, some of the finest prosciutto and kajmak (a clotted, fermented heavy cream) are produced on Zlatibor Mountain. This area is characterized by chicken, lamb and veal soups, boiled and roast meats (particularly pork), fried and roasted dishes such as janija (a shallow-fried and then braised beef dish), mutton with potatoes, coarsely chopped fermented cabbage slow-boiled with several types of meat, podvarak (sauerkraut with ribs and/or other meats smothered with a sour cream-based custard and baked), sarma (here, minced meat and rice wrapped in sauerkraut leaves and boiled), kopacki pasulj (beans with 
meat, ribs and bacon), moussaka (here, baked, layered sliced potato interspersed with pre-fried minced meat), spit-roast lamb, furnance-burnt lamb, pork and veal, lamb or chicken baked under charcoal ash, jellied calf's head with tripe - an icon of national cuisine from Loznica town - boiled lamb, tobacco crackling (finely shaven pork crackling) and pork hams.

In western Serbia, especially in the area of Zlatibor, beef and pork ham (made with pieces of meat from the back and leg) and Uzice bacon (made with pork bone side without the neck and shoulder musculature without forelegs, back and leg without shank) are traditionally produced. These products are protected by geographical indications and are produced from November to April in artisanal household and industrial conditions throughout the year (Troeger et al., 2007; Stevanovic et al., 2016). In Western Serbia, pork (tobacco) crackling from Valjevo (produced by thermal treatment of adipose tissue and oil-producing parts of the meat, neck and shoulder of pigs) has protected designation of origin. This pork crackling is produced both under household and industrial conditions (Stevanovic et al., 2016) .

Eastern Serbia, with its natural beauty and ecologically preserved areas with ethnic and ethnological variety, is full of culinary surprises. Authentic Danube fish dishes (gap, perch or carp) are characteristic of Smederevo town. Sarma here is prepared with vine leaves and minced meat, while chicken stew comes from the Vlaska region.

In eastern Serbia, Pozeravac sausage has geographical protection. This is fermented sausage with prepared from pork meat and hard fat tissue with $20 \%$ beef. The products are produced in industrial and household conditions (Stevanovic et al., 2016).

South Serbian cuisine can be regarded as typical of the Balkan Peninsula, with its influences from Bulgaria, Greece and Turkey. Barbecued (here, meaning charcoal-grilled) minced meat patties from the area around Leskovac are one of the most popular meat products with protected geographical name and origin (Stevanovic et al., 2016). In southern Serbia, dishes such as janija (here, a soup of sheep meat and vegetables), sprza (a kind of young lamb, roasted and with crispy skin) and roasted turkey on banica (a type of turkey pie) are popular.

In the gastronomy of Southwest Serbia, a strong oriental influence in noticeable, which is in accordance with the harsh climatic conditions (cold winters). Beef and sheep meat and sausages named sudzuk are commonly found in local diets.

\section{Gastronomic events in Serbia}

Food is a very important part of tourism, and according to the World Trade Organization, is a key factor in the development of the world economy. It provides structured jobs, infrastructure and development. Tourism is currently ranked fourth place in the world economy. It is of particular importance for developing countries, and hence, for Serbia, since it can significantly contribute to economic recovery. An interesting sector of tourism includes specific, sometimes targeted events such as festivals, traditional ceremonies, parades, expositions etc. Such events are global phenomena, and they equalize the attendees (regardless of their status), allow them to indulge, and perhaps even carry them away, even if briefly, from the humdrum and stress of everyday life. One of the basic characteristics of such events is the desire that they remain as they are, providing unique experiences for all visitors. In Serbia, events include some with a long tradition such as Vukov Sabor, going since 1933, and the Guca Trumpet Festival, held annually since 1961. Among the most popular events in 2016 were the Belgrade Beer Fest (900,000 visitors), Guca Trumpet Festival (900,000 visitors) and the Barbecue Festival in Leskovac (500,000 visitors). Clearly, Serbian gastrofestivals can attract great attention from visitors (http://www.turistickisvet.com). Besides the Barbecue Festival, significant events related to meat are the Bacon Festival in Kacarevo, a Smoked Ham event in Mackat, Sausage Festival in Turija and the Valjevo Pork Crackling Festival, as well as many other local and less well-known showcase events (Baltic et al., 2010a).

Food, in the context of the agricultural and food industries is, without doubt, an important resource in Serbia, although its position in the overall economy of Serbia is not high. The local cuisine is one of the most interesting aspects to tourists, often leaving the strongest impression and is also the reason for the re-arrival of many visitors. In Serbia, about one thousand different events are held annually, and in 2016, the Trumpet Festival in Guca and Exit in Novi Sad (fundamentally a music festival) produced income of 2.5 million euros (http://www.turistickisvet.com). Numerous events in Serbia, in which various rural associations participate, have become an interesting resource for the development of rural tourism. In Serbian villages, people still largely consume traditional foods and foster, in simple and harmonious ways, the culture of dining. This leaves a very good impression on tourists. Besides, knowledge and tastes are intimately intertwined. Today's interest in eating locally should enhance a general 
desire for living in a time and place with no fear, with a feeling of being protected by the known, and consuming foods that have kept their identity. The identity crisis in some European countries is partially linked to the food crises. For example, France, since 1990, has conducted an inventory of all that is being threatened by oblivion, including the country's gastronomic heritage (Pulen, 2004 b).

It is a fact that food is not only a theme in private life, but also in media. Television shows promote culinary artristy and world-famous chefs as well as foodie destinations and food production. Culinary stories are of interest to many viewers, regradless of their occupation, social status and gender.

\section{Conclusion}

From the time Slavs arrived in the Balkan Peninsula, meat has played an important role in Serbian cuisine. This especially applies to pork meat, which remains the most common type of meat in the diet of Serbian people. Serbian cuisine and and our use of meat has changed under different influences, whether it be from the impact of other national cuisines, or whether these changes resulted from industrialization, especially in the second half of the $20^{\text {th }}$ century. Such changes have affected cuisines worldwide, not just those in Serbia. Globalization and industrialization in the food sector tend to suppress traditional national cuisines. Therefore, practically all countries of the world are making enormous efforts to preserve local culinary traditions as a part of the cultural heritage of each nation. Preserving traditional cuisine has special significance for tourism. In Serbia too, in many different ways, people are actively trying to preserve local culinary traditions, including those around meat production and consumption. This is, among other things, being achieved through the long-time promotion of various festivals dedicated to local culinary traditions for meat and meat products

Disclosure Statement: No pontential conflict of interest was reported by the authors.

\section{References}

Baltic, Z. M., Djuric, J., Karabasil, N., Dimitrijevic, M., Markovic, R. \& Kilibarda, N., (2010a). Tradicionalni proizvodi od mesa u duhu dobre proizvodjacke prakse, Simpozijum tradicija i buducnost stocarstva u brdsko-planinskom podrucju sa posebnim osvrtom na Sjenicko-pestersku visoravan. Zbornik radova Sjenica, 86-107.

Baltic, Z. M., Djuric, J., Karabasil, N., Dimitrijevic, M., Markovic, R., Mirilovic, M. \& Pavlicevic, N., (2010c). Istorijski osvrt na proizvodnju mesa u Srbiji, 21. savetovanje veterinara Srbije. Zbornik referata i kratkih sadrzaja, 249-259.

Baltic, Z. M., Nedic, D., Djuric, J., Dimitrijevic, M., Karabasil, N. \& Kilibarda, N., (2010b). Hrana i vecna briga za zdravlje. Veterinarski zurnal Republike Srpske X, (1), 5-9.

Baltic, Z. M., Pecanac, B., Saric, M., Mandic, S., Filipovic, I., Djuric, J. \& Dojcinovic, S. (2011). Fermented sausages - products with a tradition. Veterinary Journal of Republic of Srpska, 11, (1), 5-11.

Baltic, Z. M., Djuric, J., Mandic, S., Pecanac, B. \& Loncina J., (2013). Consumers and Food Safety. Glasnik Hemicara, tehnologa i ekologa Republike Srpske, 11-16.

Boskovic, M., Baltic, Z. M., Ivanovic, J., Dokmanovic, M., Markovic, R., Sarcevic, D., Baltic T. (2015). Uticaj svinjskog mesa na zdravlje ljudi. Tehnologija mesa, 56, (1), $8-15$.

Colak-Antic, T. (2004). O posluzenju i ponasanju za stolom u Beogradu. Kultura, Beograd, 109/111, 340-350.

Domazet, S. (2004). Knjizevnost i hrana. Kultura, Beograd,109/111, 295-305.
Grujic, J. (1992). Etnografski zapisi Jevrema Grujica. Srpski etnografski zbornik, XCVI, Beograd, 123.

Hrasnica, F., Ivancic, D., Milosavljevic, S., Pavlovic, S., Rako, A. \& Smacelj, I. (1964). Specijalno stocarstvo. Zavod za izdavanje udzbenika SR Srbije, Beograd, 229-340.

Ikonic, P., Petrovic, Lj. Tasic, T., Dzinic, N., Jokanovic, M. \& Tomovic, V. (2010). Physicochemical, biochemical and sensory properties for the characterisation of Petrovska Klobasa (traditional fermented sausage). Acta Periodica Technologica, 41,19-31.

Ivanovic, J., Baltic, Z. M., Janjic, J., Markovic, R., Baltic, T., Boskovic, M., Djordjevic, J., Mrdovic, B. \& Jovanovic, D. (2016). Health aspects of dry-cured ham. Meat Technology, 57, (1), 39-46.

Janjic, J. (2010). Srpska kuhinja - gastronomija Srbije. Panacomp, Beograd, 1-8.

Janjic, J., Lovrenovic, M., Grujic, R., Ivanovic, J., Boskovic, M., Sarcevic, D., Glisic, M., Baltic, Z. M. (2015). Fast food in the diet of adolescent. Tehnologija mesa, 56, (2), 154-162.

Marjanovic-Dusanic, S. \& Popovic, D. (2004). Privatni zivot u srpskim zemljama srednjeg veka, Klio, Beograd, 139-163.

Markovic, S. (1907). Moj kuvar i savetnik, Beograd.

Novakovic, S. (1913). Meni za novembar-decembar 1913. Arhiv Srbije.

Popovic-Midzina, K. (1877). Veliki srpski kuvar, Novi Sad, 9.

Prosic-Dvornic, M. (2004). Kulturni i drustveni znacaj hrane tradicionalne srpske kulture. Kultura, Beograd, 109/111, 315-339. 
Pulen, Z. P. (2004a). Mondijalizacija, izmestanje i premestanje hrane. Kultura, Beograd, 109/111, 121-138.

Pulen, Z. P. (2004b). Izmedju domaceg i ekonomskog: plima i oseka kulinarstva. Kultura, Beograd, 109/111, 150-163.

Rozen, E. (2004). Njegovo velicanstvo, kralj hamburger. Kultura, Beograd, 109/111, 139-149.

Sarcevic, D., Lilic S., Djordjevic, V., Milicevic, D., Vranic D., Lakicevic B., Milijasevic, M. (2011). The role of consumer's perception and attitude in purchasing of meat and meat products. Tehnologija mesa, 52, (2), 283-290.

Spremic, M., 2004. Privatni zivot u srpskim zemljama srednjeg veka, Klio, Beograd, 139-163.

Stevanovic, J., Okanovic, Dj., Stevanetic, S., Mirilovic, M., Karabasil, N. \& Pupovac, S. (2016). Tradicionalni proizvodi - osnove za odrzivi razvoj proizvoda zivotinjskog porekla u Srbiji. Food and Feed Research, 43, (2), 127-134.

Paper received: 25.01.2018.

Paper accepted: 23.04.2018.
Troeger, K., Dederer, I., Ristic, M., Turubatovic, L., Beric, M. \& Stojanovic, A. (2007). Raw cured meat products and raw sausage from Serbia - Quality of traditionally produced products. Mitteilungsblatt der Fleischforschung Kulumbach, 46, (175), 11-20.

Vukovic, I., Petrovic, Lj., Vasilev, D. \& Saicic, S. (2011b). Mikroflora und Qualitat von nach traditinellem Verfahren herrgestllen Rowursten aus Nordserbien. Flischwirtschaft, 91, (11), 118-122.

Vukovic, I., Saicic, S. \& Vasilev, D. (2011a). Contribution to knowledge of major quality parameters of traditional (domestic) kulen. Tehnologija mesa, 52, (1), 134-139.

Zagorac, D., Bjegovic, J., Majstorovic, M. (2010). Gastronomska mapa Srbije. Zavod za proucavanje kulturnog razvitka Srbije, 1-23.

Zujovic, J. (1986). Dnevnik I. Arhiv Srbije, Beograd, 32. 